\title{
Proposal of a specific test in tennis: Test of shot speed and precision
}

\author{
Manuel Alfonso-Asencio a , Marta Hellín-Martínez ${ }^{b}$, Bernardino Javier Sánchez-Alcaraz \\ Martínez ${ }^{\mathrm{c}}$, \& Ruperto Menayo ${ }^{\mathrm{d}}$ (it) \\ ${ }^{\mathrm{a}}$ Ministry of Education, Valencian Community, Spain. ${ }^{\mathrm{B}}$ Faculty of Educational Sciences, Universidad de \\ Murcia, Spain, ${ }^{\mathrm{C}}$ Faculty of Sports Sciences, University of Murcia, Spain. ${ }^{\mathrm{d}}$ Faculty of Education, University of \\ Extremadura, Badajoz, Spain.
}

\section{ABSTRACT}

Tennis is a sport in which various variables related to performance influence the final result of a match. The speed and precision of the shots are among the most decisive of them. The objective of this study was to develop a test to assess the performance in terms of the speed and the precision of the forehand, backhand and serve of tennis players. The sample consisted of 4 amateur players. The analysis of the data obtained in the test provides the coach with information about the level of performance of the players and their progression.
Key words: tennis, performance, speed, precision.

Received: 18 May 2020

Accepted: 20 June 2020

Corresponding author:

Manuel Alfonso-Asencio, Ministry of Education,

Valencian Community, Spain.

Email:

alfonso_manase@gva.es

\section{INTRODUCTION}

Tennis is a sport that is characterised by a great variety of strokes, among which, due to its greater frequency, the serve, the forehand and the backhand stand out (Baiget, Iglesias, Vallejo, and Rodríguez, 2011; Kovalchik and Reid, 2017). Tennis competition demands from players a high degree of technical precision in stroke production, being a fundamental component to achieve good performance (Haake, Chadwick, Dignall, Goodwill and Rose 2001; Menayo, Fuentes, Moreno, Clemente and García, 2008). Different studies have shown a direct relationship between technical ability (measured through the level of precision and speed of the shots) and the competitive level of the tennis player (Kovacs, 2007; Reid, Crespo, Lay and Berry, 2007; Urbán, Hernández-Davó and Moreno, 2012).

With the aim of understanding the technical ability of the players, the literature has proposed a wide variety of tests to evaluate the precision and speed of tennis shots in different game situations, considering parameters of shot resistance and performance (Ferrauti Kinner, and Fernández-Fernández, 2011; Lyons, AlNakeed, Hankey and Nevill, 2013; Vergauwen, Madou and Behets, 2004). These studies have allowed to design instruments for the evaluation of the player's technique, simulating the physical demands of tennis competition. These instruments are of special interest when designing specific tennis training sessions (Fernández-Fernández et al., 2012). Therefore, the objective of this study was to design a test to assess the performance in terms of speed and precision of the forehand, backhand and serve of tennis players.

\section{METHODOLOGY}

Participants

The study sample consisted of a total of 4 amateur junior tennis players with ages between 11 and 14 years (mean age $12.75 \pm$ 1.50 years).

Protocol for the development of the test

The development of the test of speed and precision in tennis strokes is presented. This test evaluates the variables of speed and precision in the forehand, backhand and serve in prolonged playing situations. The design of the test has been based on similar previous research in tennis (Fernández-Fernández et al., 2012). Prior to the test, the players must perform a 5 minute general warm-up and a 10 minute specific warm-up (AlfonsoAsencio and Menayo, 2019). 
The test procedure consists of conducting three blocks of exercises for each stroke (Figure 1). In block I the player performs forehands, in block II performs backhands, and in block III performs serves. The player rests 90 seconds between each block of exercises, and 20 seconds between each series of strokes. Before performing the test, the players should be instructed to try to achieve the highest speed in their strokes while maintaining precision. In addition, players should be instructed to recover to the centre of the court after each forehand and backhand hit.

\begin{tabular}{|c|c|c|c|}
\hline \multicolumn{4}{|c|}{ Test of precision and speed of tennis shots } \\
\hline Warm up & $\begin{array}{l}\text { Block } \\
\text { Forehand }\end{array}$ & $\begin{array}{ll}\text { Block } & \text { II. } \\
\text { Backhand } & \end{array}$ & $\begin{array}{l}\text { Block III. } \\
\text { Serve }\end{array}$ \\
\hline \multirow{2}{*}{$\begin{array}{l}\text { General warm } \\
\text { up } \\
\text { Joint mobility } \\
\text { Movement } \\
\text { Jumps }\end{array}$} & $\begin{array}{llr}\text { Serie } & 1 . & 6 \\
\text { crosscourt } & \text { FHs }\end{array}$ & $\begin{array}{lcr}\text { Serie } & 1 . & 6 \\
\text { crosscoourt } & \text { BHs }\end{array}$ & Right side \\
\hline & $\begin{array}{lcr}\text { Serie } \quad 2 . & 6 \\
\text { crosscourt FHs }\end{array}$ & $\begin{array}{lrr}\text { Serie } & 2 . & 6 \\
\text { crosscourt } & \text { BHs }\end{array}$ & $\begin{array}{l}\text { Serie } 1.10 \\
\text { wide serves }\end{array}$ \\
\hline \multirow{4}{*}{$\begin{array}{l}\text { Specific warm } \\
\text { up } \\
\mathrm{FH} \mathrm{\&} \mathrm{BH} \\
\text { shadows } \\
\mathrm{FH} \& \mathrm{BH} \text { with } \\
\text { movement } \\
\text { Serves }\end{array}$} & $\begin{array}{llr}\text { Serie } & 3 . & 6 \\
\text { crosscourt FHs }\end{array}$ & $\begin{array}{lrr}\text { Serie } & 3 . & 6 \\
\text { crosscourt } & \text { BHs }\end{array}$ & $\begin{array}{l}\text { Serie 2. } 10 \\
\text { wide serves }\end{array}$ \\
\hline & $\begin{array}{lcc}\text { Serie } & 4 . & 6 \\
\text { crosscourt FHs }\end{array}$ & $\begin{array}{lcc}\text { Serie } & 4 . & 6 \\
\text { crosscourt } & \text { BHs }\end{array}$ & Left side \\
\hline & $\begin{array}{lrr}\text { Serie } & 5 . & 6 \\
\text { crosscourt } & \text { FHs }\end{array}$ & $\begin{array}{lrr}\text { Serie } & 5 . & 6 \\
\text { crosscourt } & \text { BHs }\end{array}$ & $\begin{array}{l}\text { Serie 1. } 10 \\
\text { " } T \text { " serves }\end{array}$ \\
\hline & $\begin{array}{lrr}\text { Serie } & 6 . & 6 \\
\text { crosscourt } & \text { FHs }\end{array}$ & $\begin{array}{lrr}\text { Serie } & 6 . & 6 \\
\text { crosscourt } & \text { BHs }\end{array}$ & $\begin{array}{l}\text { Serie 2. } 10 \\
\text { "T" serves }\end{array}$ \\
\hline
\end{tabular}

Figure 1. Development protocol of the speed and precision test of the forehand, backhand and serve in tennis.

The points of maximum precision for the shots are: i) forehand and backhand shots: intersection of the baseline and the singles line; ii) open service: intersection of the singles line and the service line; iii) service to zone $\mathrm{T}$ : intersection of the line dividing the serve boxes and the service line.

\section{Instruments}

Speed: A radar with an accuracy of $\pm 1 \mathrm{~km} / \mathrm{h}$ is used to record the output ball speed.

Accuracy: During the test, a video camera is used to record the bounce of the ball, at least at $240 \mathrm{fps}$.

Ball feeding: A ball machine is used to feed the balls to the blocks I and II with the same speed, precision, and frequency. Before carrying out the test, it is necessary to calibrate and verify the correct operation of the machine.

Instrument placement during the test

Block I - Forehand and Block II - Backhand
The radar is placed on a 1-metre high tripod behind the player, at a distance of 3 metres from the baseline, 2-metres from the singles line and directed towards the direction of the shots. This radar placement is used on both the left and right sides of the court. A coach or an assistant will be placed besides the radar to write down the ball speed of each shot on a log sheet. On the other hand, the video camera is placed on a tripod 1 metre from the extension of the singles line and 4.5 metres from the baseline. Finally, the ball machine is placed on the baseline and 2 metres from the singles line. Figure 2 shows the placement of the radar, the ball machine, the video camera and the directions of the shots during the test.

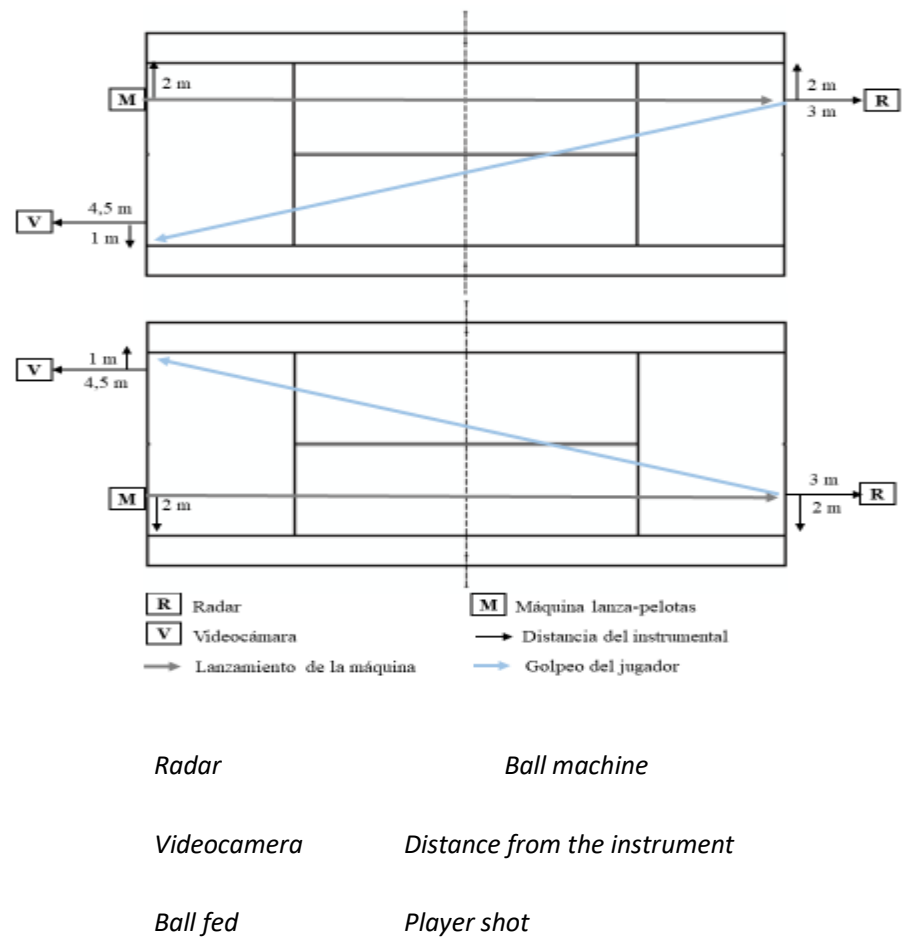

Figure 2. Position of the instruments used and the directions of the shots in block I-forehand (court below) and block II - backhand (court above).

Block III - Service

In block III, the radar is placed on a tripod 2 metres high behind the player and at a distance 1.5 metres from the centre line and 3 metres from the baseline. To avoid measurement errors, the radar is oriented in the direction of the serves. On the other hand, the video camera is placed on a tripod at a height of 2 metres, above the baseline. When hitting wide serves, the player stands at the intersection of the baseline and singles line. When serving " $T$ " serves, the player stands on the central service line. Figure 3 shows the placement of the radar, the video camera and the direction of the serves during the test. 


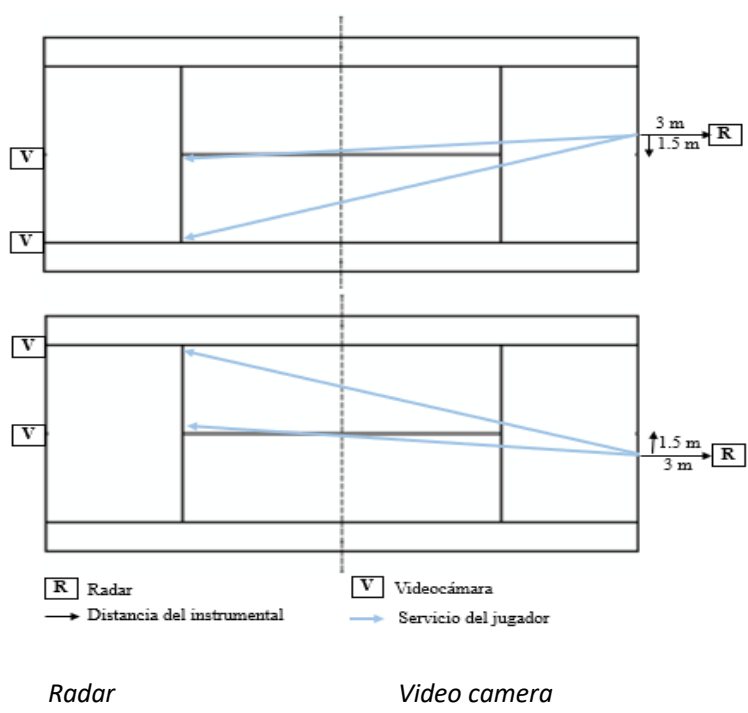

Distance from the instrument Serve of the player

Figure 3. Position of the instruments used and the direction of serves in block III - service for the right side (court above) and for the left side (court below).

\section{Analysis of the test data}

Once the test was finalised, ball bounces were digitalised using the software Kinovea to later export data to a spreadsheet. The shot precision was determined by radial error (ER), measuring the distance from the ball bounce to the point of maximum precision. The formula used was the one proposed by Van den Tillar and Ettema (2003), specifically:

$$
E R=\sqrt{\left(x-x^{\prime}\right)^{2}+\left(y-y^{\prime}\right)^{2}}
$$

Finally, the speed and precision data were transferred to a spreadsheet for statistical analysis.

\section{RESULTS}

Table 1 shows the results of ball speed and precision in the serve and backhand shots obtained by each player. It should be noted that the data related to the forehand will be analysed in future research.

Table 1. Descriptive results of the ball speed and precision obtained by each player in the serve and backhand shots.

\begin{tabular}{lllll}
\hline Player & $\begin{array}{l}\text { Serve } \\
\text { Speed } \\
(\mathrm{km} / \mathrm{h})\end{array}$ & $\begin{array}{l}\text { Precision } \\
(\mathrm{cm})\end{array}$ & $\begin{array}{l}\text { Backhand } \\
\text { Speed } \\
(\mathrm{km} / \mathrm{h})\end{array}$ & $\begin{array}{l}\text { Precision } \\
(\mathrm{cm})\end{array}$ \\
\hline $\mathbf{1}$ & $116.4 \pm 6.1$ & $238.0 \pm 161.173 .5 \pm 5.8$ & $481.0 \pm 229.2$ \\
$\mathbf{2}$ & $121.3 \pm 10.2$ & $225.1 \pm 66.0$ & $69.2 \pm 5.5$ & $368.7 \pm 152.8$ \\
$\mathbf{3}$ & $142.5 \pm 13.3$ & $249.1 \pm 269.471 .7 \pm 8.2$ & $385.1 \pm 176.27$ \\
$\mathbf{4}$ & $118.5 \pm 7.8$ & $242.4 \pm 96.571 .6 \pm 6.9$ & $449.5 \pm 175.4$ \\
\hline
\end{tabular}

\section{CONCLUSIONS AND PRACTICAL APPLICATIONS}

The objective of this test was to register the speed and precision of the forehand, backhand and serve shots in tennis through a simple protocol with inexpensive instruments. These variables are determinant in the player's performance (Menayo et al., 2008) and their progresson, allowing to determine the suitability of the training programs developed. Finally, future studies are encouraged to implement this test to find out the speed and precision values of the players according to different variables such as age, gender or level of play.

\section{REFERENCES}

Alfonso-Asencio, M., y Menayo, R. (2019). Induced variability during the tennis service practice affect the performance of every tennis player individually and specifically. European Journal of Human Movement, 43, 86-101.

Fernández-Fernández, J., Sanz, D., Moya, M., González de la Aleja, J., Ávila, F., y Méndez-Villanueva, A. (2012). Propuesta de un test para evaluar a los jugadores de tenis ante situaciones de golpeo prolongadas y variadas: tennis hitting test. Revista $E$ Coach, 13, 1-8.

Ferrauti, A., Kinner, V., y Fernández-Fernández, J. (2011). The Hit \& Turn Tennis Test: An acoustically controlled endurance test for tennis players. Journal of Sport Sciences, 29(5), 485-494, https://doi.org/10.1080/02640414.2010.539247

Haake S.S., Chadwick, S.G., Dignall, R. J., Goodwill, S., y Rose P. (2000). Engineering tennis - slowing the game down. Sports Engineering, 3(2), 1-12, https://doi.org/10.1046/j.14602687.2000.00040.x

Kovacs, M.S. (2007). Tennis physiology: training the competitive athlete. Sports Medicine, 37(3), 189-198, https://doi.org/10.2165/00007256-200737030-00001

Kovalchik, S. A., y Reid, M. (2017). Comparing Matchplay Characteristics and Physical Demands of Junior and Professional Tennis Athletes in the Era of Big Data. Journal of Sports Science and Medicine, 16, 489-497.

Lyons, M., Al-Nakeeb, Y., Hankey, J., y Nevill, A. (2013). The effect of moderate and high-intensity fatigue on groundstroke accuracy in expert and non-expert tennis players. Journal of Sports Science \& Medicine, 12(2), 298-308.

Menayo, R., García, J.P.F., Hernández, F.J.M., Clemente, R., y Calvo, T.G. (2008). Relación entre la velocidad de la pelota y la precisión en el servicio plano en tenis en jugadores de perfeccionamiento. European Journal of Human Movement, 21, 17-30.

Reid, M., Crespo, M., Lay, B., y Berry, J. (2007). Skill acquisition in tennis: research and current practice. Journal of Science and Medicine in Sport, 10(1), 1-10, https://doi.org/10.1016/j.jsams.2006.05.011

Urbán, T.; Hernández-Davó, H., y Moreno, F. J. (2012). Variabilidad cinemática en relación con el rendimiento en el saque en jóvenes tenistas. Motricidad. European Journal of Human Movement, 29, 49-60.

Van den Tillar, R., y Ettema, G. (2003). Instructions emphasizing, velocity, accuray, or both in performance and kinematics of overarm throwing. Perceptual Motor Skills, 103, 503-514, https://doi.org/10.2466/pms.103.2.503-514

Vergauwen, L., Madou, B., y Behets, D. (2004). Authentic 
evaluation of forehand groundstrokes in young low- to intermediate-level tennis players. Medicine and Science in Sports and Exercise, 36(12), 2099-2106, https://doi.org/10.1249/01.MSS.0000147583.13209.61

RECOMMENDED ITF TENNIS ACADEMY CONTENT (CLICK BELOW)

\section{ITF Academy}

Copyright (c) 2020 Manuel Alfonso-Asencio, Marta Hellín-Martínez, Bernardino Javier Sánchez-Alcaraz Martín, \& Ruperto Menayo

\section{(a) (1)}

This text is under a Creative Commons BY 4.0 license

You are free to Share - copy and redistribute the material in any medium or format - and Adapt the content - remix, transform, and build upon the material for any purpose, even commercially under the following terms:

Attribution: You must give appropriate credit, provide a link to the license, and indicate if changes were made. You may do so in any reasonable manner, but not in any way that suggests the licensor endorses you or your use.

CCBY4.0 license terms summary CCBY4.0license terms 